vomiting disease is less clear. Various viruses have been implicated, mostly discovered by electron microscopy of stools. Unfortunately none of the candidate viruses grow in tissue culture and this has greatly hampered investigation of their pathogenicity. Nevertheless, techniques such as feeding the viruses to volunteers and immune electron microscopy have yielded much useful information. The main viruses found by these methods have been the Norwalk, ${ }^{5}$ Montgomery County, and Hawaii agents in the United States, ${ }^{6}$ and the W, ${ }^{7}$ Harlow, and Ditchling agents ${ }^{9}$ in Britain. By far the best studied of these is the Norwalk agent, but several general conclusions about all of them have emerged. The viruses are small (they are all about the same size ${ }^{9-11}$ ) and in most cases feeding them to volunteers reproduces alimentary symptoms. ${ }^{6}$ 7 11-13 Antibody is produced after both natural and experimental infections. ${ }^{101113}$ The relations between the viruses are confused. The Norwalk and Montgomery County agents are antigenically similar but differ from the Hawaii agent. ${ }^{11}$ The British W and Ditchling agents appear identical but they in turn differ from both Norwalk and Hawaii agents. ${ }^{6} 9$ Recently, another virus which appears identical with the Norwalk agent on electron microscopy has been reported in a hospital and community outbreak in Britain, though its antigenic relation to the Norwalk virus is unknown. ${ }^{14}$

Now a calicivirus has turned up as a cause of winter vomiting disease. $^{1516}$ Caliciviruses have a distinctive appearance ${ }^{17}$ and are best known as faecal viruses of such diverse species as sealions, pigs, and cats. ${ }^{18}$ The human variety was first reported by Madeley and Cosgrove ${ }^{19}$ but without any association with disease. Flewett and Davis confirmed finding calicivirus in human stools, but in this instance in two babies with gastroenteritis. ${ }^{20}$ Cubitt, McSwiggan, and Moore ${ }^{16}$ have now reported calicivirus associated with a typical outbreak of winter vomiting disease in a London school. The virus was present in the stools of seven of the 13 children affected. All the children developed antibody, though a teacher (the only adult affected) did not. Virus disappeared from the stools by the sixth day after onset and could not be found in the stools of healthy children in the school. This is convincing evidence that calicivirus caused the outbreak. Confirmation of the role of calicivirus in alimentary infections has also come from Japan, where Chiba and his colleagues $^{21}$ found it to be the cause of an outbreak of acute infectious diarrhoea in an infant's home. Here again the problem of differentiating winter vomiting from acute nonbacterial gastroenteritis becomes apparent.

Calicivirus is certainly not the only cause of winter vomiting disease, and in any event it may sometimes be present in the stools of babies without symptoms. ${ }^{22}$ The part played by the various viruses reported in both winter vomiting disease and acute non-bacterial gastroenteritis will be worked out only by thorough virological investigation of outbreaks, preferably notified at an early stage when specimens are available from patients with acute disease.

${ }^{1}$ Zahorsky J. Hyperemesis hiemis or the winter vomiting disease. Arch Pediatr $1929 ; 46: 391-5$.

2 Silverton Ml. An outbreak of illness at Rye Grammar School. Med Officer $1952 ; 88: 215$

${ }^{3}$ Bishop RF, Davidson GP, Holmes IH, Ruck BJ. Evidence for viral gastroenteritis. N Englf Med 1973;289:1096-7.

4 Flewett TH. Implications of recent virological researches. Ciba Foundation Symposium 1976;42:237-50.

${ }^{5}$ Adler JL, Zickl R. Winter vomiting disease. F Infect Dis 1969;119: 668-73.

${ }^{6}$ Wyatt RG, Dolin R, Blacklow NR, et al. Comparison of three agents of acute infectious nonbacterial gastroenteritis by cross-challenge in volunteers. F Infect Dis 1974; 129:709-14.
7 Clarke SKR, Cook GT, Egglestone SI, et al. A virus from epidemic vomiting disease. $\mathrm{Br} \mathrm{Med} \mathcal{F} 1972: \mathrm{iii}: 86-9$.

8 Appleton H, Higgins PG. Viruses and gastroenteritis in infants. Lancet $1975 ; \mathrm{i}: 1297$.

9 Appleton H, Buckley M, Thom BT, Cotton JL, Henderson S. Virus-like particles in winter vomiting disease. Lancet 1977; i:409-11.

${ }^{10}$ Kapikian AZ, Wyatt RG, Dolin R, Thornhill TS, Kalica AR, Chanock RM. Visualisation by immune electron microscopy of a $27-\mathrm{nm}$ particle associated with acute infectious nonbacterial gastroenteritis. $\mathcal{f}$ Virol 1972;10:1075-8.

11 Thornhill TS, Wyatt RG, Kalica AR, Dolin R, Chanock RM, Kapikian AZ. Detection by immune electron microscopy of 26 to $27 \mathrm{~nm}$ viruslike particles associated with two family outbreaks of gastroenteritis. $\mathcal{J}$ Infec Dis 1977:135:20-7.

12 Dolin R, Blacklow NR, DuPont $\mathrm{H}$, et al. Transmission of acute infectious nonbacterial gastroenteritis to volunteers by oral administration of stool filtrates. F Infect Dis 1971:123:307-12.

${ }^{13}$ Dolin R, Levy AG, Wyatt RG, Thornhill TS, Gardner JD. Viral gastroenteritis induced by the Hawaii agent. Jejunal histopathology and serologic response. $A m \mathcal{F} M e d$ 1975; 59:761-8.

${ }^{14}$ Caul EO, Ashley C, Pether JVS. "Norwalk"-like particles in epidemic gastroenteritis in the UK. Lancet $1979 ; \mathrm{ii}: 1292$.

15 McSwiggan DA, Cubitt D, Moore W. Calicivirus associated with winter vomiting disease. Lancet $1978 ; \mathrm{i}: 1215$.

${ }^{16}$ Cubitt WD, McSwiggan DA, Moore W. Winter vomiting disease caused by calicivirus. $\mathcal{f}$ Clin Pathol $1979 ; 32: 786-93$.

${ }^{17}$ Madeley CR. Comparison of the features of astroviruses and caliciviruses seen in samples of feces by electron microscopy. F. Infect Dis 1979; 139:519-23.

18 Andrews CH, Pereira HG, Wildy P. Viruses of vertebrates. 4th ed. London: Ballière Tindall, 1978;38-41.

19 Madeley CR, Cosgrove BP. Caliciviruses in man. Lancet 1976; i:199-200.

${ }^{20}$ Flewett TH, Davies H. Caliciviruses in man. Lancet 1976;i:311.

${ }^{21}$ Chiba S, Sakuma Y, Akihara $M$, Kogasaka R, Hoyino $K$, Nakao $T$. Stool viruses in babies in Glasgow 3. Community studies. In International Conference on Infant Nutrition and Diarrhoeal Disease. Kuala Lumpur, 1979.

${ }^{22}$ Scott TM, Madeley CR, Cosgrove BP, Stanfield JP. $f$ Hyg 1979;83: 469-85.

\section{Drugs and alcohol}

One elderly diabetic taking tolbutamide asked his doctor if he might have a drink to celebrate Christmas; he was told categorically that he must not. No doubt the harassed doctor, aware of the complex interactions between drugs and alcohol, ${ }^{1}$ must have thought a blanket prohibition the safest expedient.

A highly simplified view of the body's handling of alcohol may provide some guidance. Alcohol in social amounts increases gastric absorption, is freely distributed in the body water, and is eliminated in the liver by conversion to acetaldehyde with the aid of the cytosol enzyme alcohol dehydrogenase. Acute intoxication may induce pylorospasm, which will delay drug absorption. Furthermore, the alcohol will interact with microsomal enzymes responsible for drug metabolism, probably because they are brought into play to assist alcohol dehydrogenase in dealing with the excess or because stimulation of adrenocortical steroids inhibits microsomal enzymes. Repeated ingestion of alcohol (and cigarette smoking) leads to induction of drug-metabolising enzymes, so that the alcoholic may be less sensitive to drugs, provided that his liver is not seriously damaged.

In general, therefore, the acute effect of alcohol is to inhibit drug metabolism so that drug action is prolonged. In man this has been shown with phenylbutazone, phenobarbitone, meprobamate, and chloral hydrate. ${ }^{2} \mathrm{~A}$ similar action occurs with other barbiturates, opiates, and antipyrine after addition of alcohol in vitro and after its administration to animals. Diazepam has a strong synergistic action with alcohol, but with other benzodiazepines the action is weaker and they may be safer in certain circumstances. Anti- 
depressants and antipsychotic drugs, especially those with strong anticholinergic properties such as amitryptiline, have an additive effect with alcohol, which can provoke extrapyramidal symptoms in patients on long-term treatment. ${ }^{3}$ Barbiturates, beta-blockers, and antihistamines have all been shown to impair psychomotor performance, even in small doses, in conjunction with alcohol. The risks of hypoglycaemia with the sulphonylureas and of bleeding with warfarin should both be well known. Poisoning with relatively small doses of drugs like barbiturates, opiates, diazepam, chlormethiazole, paracetamol, and Distalgesic (dextropropoxyphene and paracetamol) seems to be more serious, and sometimes unexpectedly fatal, when combined with alcohol. The evidence is largely anecdotal and the explanation is not known, though central nervous system interactions are probably important.

In contrast, drugs which are metabolised by the liver are likely to have a diminished effect in the chronic alcoholic (in the absence of cirrhosis) because of enzyme induction. This is true for phenytoin, meprobamate, diazepam, barbiturates, warfarin, and tolbutamide, ${ }^{4}$ the therapeutic actions of which may be reduced by as much as half. Enzyme induction may also explain the very large amounts of sedatives that sometimes have to be given to patients with alcohol-withdrawal symptoms.

Drugs may themselves affect the behaviour of alcohol by altering gastric absorption, by changing its volume of distribution (in the case of diuretics, for example), and by inhibiting its metabolism. Chlorpromazine and chloral hydrate inhibit alcohol dehydrogenase and disulfiram (Antabuse) interferes with aldehyde dehydrogenase, though the belief that accumulation of acetaldehyde is responsible for the "Antabuse reaction" is probably too simple. ${ }^{5}$ Chlorpropamide and metronidazole produce flushing and an "Antabuse reaction" in some people, but this is almost certainly genetically determined, at least in the case of chlorpropamide. ${ }^{6}$ Flushing is probably mediated through central receptors in the brain, and drugs such as naloxone may be effective in treating acute alcoholic intoxication. ${ }^{7}$ Greater knowledge of such drug-receptor interactions may help to identify individual susceptibility to the effects of both drugs and alcohol.

${ }^{1}$ Linnoila M, Mattila, MJ, Kitchell BS. Drug interactions with alcohol. Drugs 1979;18:299-311.

2 Rubin E, Gang H, Misra PS, Lieber CS. Inhibition of drug metabolism by acute ethanol intoxication. Am $\mathcal{F}$ Med 1970;49:801-6.

3 Lutz EG. Neuroleptic-induced akathisia and dystonia triggered by alcohol. F Am Med Ass 1976;236:2422-3.
${ }^{4}$ Iber FL. Drug metabolism in heavy consumers of alcohol. Clin Pharmacol Therap 1977;22:735-42.

5 Sauter AM, Boss D, von Wartburg JP. Re-evaluation of the disulfiramalcohol reaction in man. F Stud Alc 1977;38:1680-95.

6 Leslie RDG, Pyke DA. Chlorpropamide-alcohol flushing: a dominantly inherited trait associated with diabetes. $B r$ Med f 1979 ;ii:1519-21.

7 Jefferys DB, Flanagan RJ, Volans GN. Reversal of ethonal-induced coma with naloxone. Lancet 1980;i:308-9.

\section{The editor regrets ...}

Last year the $B M F$ rejected over 4000 articles submitted for publication, so making some of their authors angry, or frustrated, or simply miserable. Some of these articles were accounts of good medical science, were well written, and because of their lack of general interest were turned down in our weekly competitive editorial hanging committee (so-called by analogy with the committee that selects paintings for the Royal Academy's summer exhibition). Most of the rejects, however, were non-starters.

Many of the rejected case reports were rarities that had been recorded already-sometimes in standard textbooks. Oddities are of wide interest only the first time round. Clinical research appeals to general readers when it is reasonably conclusive, but many of the papers sent to us were far too preliminary. The acid test is whether the findings will affect clinical practice, and that means that ideas should have been tested on patients, probably in controlled trials. Nor do we usually accept refutations of hypotheses originally published in another journal-though we do accept an obligation when we carried the first paper. Next, since our readers are mostly generalists, we give priority to papers on common disorderscoronary disease, breast cancer, stillbirth, rheumatoid arthritis -and look more sceptically at work (even of high quality) on clinical rarities. Every editor has his ideal paper (as every motorist dreams of an ideal car). For us the paper would report new findings in a common disease that either improved prognosis or simplified management: and the new approach would have been properly evaluated in a formal controlled trial.

Finally, what about presentation? Clearly a well-written, cleanly typed paper makes a good impression on both editors and referees, but we try to assess the quality of the work as well. Sometimes-as Dr Alex Paton explains at p 529-we decide to rewrite a paper heavily because its ideas are important and attractive but not expressed appropriately for the average non-specialist reader. Most often, however, we cannot find the time to provide such a service, so we hope intending authors will find this example helpful.

\section{Correction}

\section{Cerebral atrophy or hydrocephalus?}

We regret that the list of references was omitted from the leading article on this subject (9 February, $p$ 348). They are as follows:

${ }^{1}$ Marsden CD, Harrison MJG. Outcome of investigation of patients with presenile dementia. Br Med f 1972; ii :249-52.

2 Adams RD, Fisher CM, Hakim S, Ojemann RG, Sweet WH. Symptomatic occult hydrocephalus with "normal" cerebrospinal-fluid pressure. A treatable syndrome. $N$ Engl f Med 1965;273:117-26.

${ }^{3}$ Hakim S, Adams RD. The special clinical problems of symptomatic hydrocephalus with normal cerebrospinal fluid pressure. Observations on cerebrospinal fluid hydrocephalus. F Neurol Sci 1965;2:307-27.

4 Vassilouthis J, Richardson AE. Ventricular dilatation and communicating hydrocephalus following spontaneous subarachnoid hemorrhage. f Neurosurg 1979;51:341-51.
5 Wyper DJ, Pickard JD, Matheson M. Accuracy of ventricular volume estimation. F Neurol Neurosurg Psychiatry 1979;42:345-50.

6 Bannister R, Gilford E, Kocen R. Isotope encephalography in the diagnosis of dementia due to communicating hydrocephalus. Lancet 1967;ii: 1014-7.

7 Hill ME, Lougheed WM, Barnett HJM. A treatable form of dementia due to normal pressure communicating hydrocephalus. Can Med Assoc $\mathcal{F}$ 1967;97:1309-20.

${ }^{8}$ Illingworth RD, Logue V, Symon L, Uemura K. The ventriculocaval shunt in the treatment of adult hydrocephalus results and complications in 101 patients. $\mathcal{f}$ Neurosurg $1971 ; 35: 681-5$.

9 Ostertag CB, Mundinger F. Diagnosis of normal-pressure hydrocephalus using CT with CSF enhancement. Neuroradiology $1978 ; 16: 216-9$.

10 Chawla JC, Hulme A, Cooper R. Intracranial pressure in patients with dementia and communicating hydrocephalus. $\mathcal{F}$ Neurosurg 1974;40: 376-80.

11 Symon L, Dorsch NWC. Use of long-term intracranial pressure measurement to assess hydrocephalic patients prior to shunt surgery. f Neurosurg 1975;42:258-73. 